\title{
Peering Into Culture of Ancient Bukhara
}

\author{
Khudoev G. M. \\ Uzbekistan State Conservatory, Tashkent, Uzbekistan
}

\begin{abstract}
Ancient Bukhara is the cultural and educational center of East which made huge contribution to a treasury of world art. Culture and art buildings were built in Bukhara and around its territory. Ancient Bukhara turned out as one of the biggest centers of Middle East in the period (era) of outstanding Somoniy (in the IX-X centuries) and Temurids (in the XIV-XV centuries), particular, its developed literature, culture, architecture, and music art; especially, as being the capital of dynasty Mangits (at the beginning of the century XVIII-XX), served as the groundwork of forming Shashmakom samples in groups. This time among a number of poets and artists, lived Akhmad Danish — the most mature scientist, philosopher, poet, calligrapher, and painter, Abdurauf Fitrat — poet and writer, theoretician, musician and political activist.
\end{abstract}

Keywords: palace, Ancient Bukhara, archeological monuments, architectural monuments, culture, era of Temurids, fine art, music art, Shashmakom

\section{Introduction}

Bukhara which made a huge contribution to a treasury of world art is well-known to the world community as the cultural and educational center of the ancient East. Since old years in our country and abroad, Bukhara was famous for musical culture, architectural monuments, subjects of applied art, and jewelry.

Bukhara and its vicinities were the center of emergence of the highest culture and art. It can be seen as the example of excavation of monuments in the town of Varakhsha located in the Jondor region. The found remains of destructions in ancient Varakhsha testify that our ancestors owned high culture of a wall art list, a construction of monuments and production of products of applied art.

In 40 kilometers to the West from Bukhara the biggest building of Varakhsha occupying the space of nine hectares and height in 10 meters was built. "In this building in the time the government palace and a chapel, military department and warehouses of arms (arsenal) were located.Walls of the palace decorated with painting works, drawings, in rooms various sculptures are located" (Khasanov, 2009, p. 62).

And though sculptures and wall painting are dated the VI-VII centuries, their roots are in an extreme antiquity that draws attention to them many art critics. In the palace under a layer of a ganch, it is possible to find various sketches from life of governors - musical scenes, episodes based on dastan, pictures and landscapes of the local nature. About it the doctor of art studies, Professor M. Kadirov noted:

At the palace of Bukhara governors from time immemorial there were some groups of singers and musicians: During the pre-Islamic period among them there were also famous dancers. Archeological excavations in Varakhsha confirmed

Khudoev G. M., Fine Art Expert, Scientific Researcher, Uzbekistan State Conservatory. 
this fact relating to the VIII century. Scarfs (handkerchief) and decoration of dancers were so found. On one sculpture the dancer holds a scarf in hand, the eye is turned lengthways. In modern dances too uses reception with the fallen scarf. (Kodirov, 1997, p. 131)

In the XI-X centuries when the powerful dynasty of Samonid came to the power, Bukhara as the capital turned into one of the largest cultural centers of the Middle East. Here the science, culture, art, music prospered, in particular great scientists, poets, musicians Rudaki, Narshakhi, Abu Khafs Sugdi (in the IX century), Tokhir Abutayibi (in the IX-X centuries), Alibek Tanburi (in the IX-X centuries), Abulabbos Bakhtiyor (in the IX-X centuries), Abu Nasr Mutrib (in the X century), and later (at the end of X century to the beginning of the IX century) Abu Ali ibn Sino; art of monuments was developed. During the subsequent Eras, Bukhara was the state capital of Korakhit (XI) and Korakhanid (XII), and in the XIII century as many other cities of Central Asia, underwent destruction in connection with invasion of troops of Chingizkhan. In the XIV-XV centuries, Bukhara was in structure of the state of Temurid. During this period revival of its culture was observed.

Thus, it is possible to claim that at the initiative of Amir Temur in the XIV century many ancient sights of Bukhara were restored, and some were constructed anew. In 1380, Amir Timur restored the holy site of generation in the building Chashma Ayub the ancient mosque outside the city was arranged well. Sayfiddin Bokharzy and Bayenkulikhon's tombs and vicinities were also equipped during an era of manifestation of Amir Temur (Amir Temur in world history, 2001, p. 151).

During this period reforming development of other spheres of art, in particular music was observed.

In the Middle Ages city the population traditionally lived in the makhallyas which were formed mainly on occupation characteristics. Musicians, artists, famous in the people, united in collective and for convenience lodged in the neighborhood. Therefore existed streets of composers, poets, musicians, singers. Owners of such professions enjoyed special authority, round them schools of creative skill and performance were formed. (Amir Temur in world history, 2001, p. 181)

This tradition found the reflection in Ancient Bukhara and not only remained up to the XIX century, but also gained the development. So, in Bukhara, the population of actors took the whole quarter, in the first half of the XIX century lived 40 families representatives of art here.

The French traveler Demezon who visited Bukhara in 1834 wrote:

The local population has a custom - to note the birth of the child or any joyful family event loud music, most often game on a doyra and the surnay, acquainting with pleasure all population. Some musicians served directly in the Arch residence of the Bukhara emir. If there was any important event or a holiday musicians from above of gate (or walls) the Arch playing tambourines (doyra) and the surnay notified all city. Palace "Ensemble" consisted of 8 players on doyra and 8 on surnay. And in a month of Ruza (a Muslim post) in certain days played since evening till the dawn. ${ }^{1}$

Amir Temur deeply felt and understood music and practically used its influence to people. During festive events in Sokhibkiran's palace always listened to makom performed by famous singers, estimated kindly again created works. The governor understood force and value of art for all population of the palace. (Amir Temur in world history, 2001, p. 182)

In our opinion, exactly from that time makom started being formed as a classical genre of art. The statement below confirms this thought:

Originally makom at the same time appeared in culture of the people of the Middle East. Since an era of Temurid

${ }^{1}$ See M. Kodirov (1997). Holiday and festivals // Bukhara-East pearl, p.134. 
local features started influencing this process, and makom got local shades of execution. The composition of makom began to differ from initial, it was more free. The general recognition was gained by 12 Arab makom, 12 Uigur, 7 Iranian and 7 Azerbaijani, 6 Uzbek and Tajik makom. (Amir Temur in world history, 2001, p. 182)

The image of cultural Bukhara revealed in new beauty in the XVI-XVII centuries, especially, when Bukhara became the capital center of Shayboniy (in the XVI century), then ashtarkhoniy (in the XVII century) and mangit (in the XVIII-XIX centuries). Not only in Bukhara, but also in all applying territories the culture roughly developed. The memorial monuments which reached us, subjects of folk applied art, classical music in form Shashmakom, the Bukhara miniature are recognized by the leading art critics of the world as a model of high art.

In the XVIII century, in the region there were conflicts, revolutions, and at last, after seizure of power by foreigners at the end of XVIII and the beginning of the XIX century political stability which created the soil for cultural development was established. In the middle of the XIX century, there was the whole group of talented representatives of art: among them famous poets and artists Mir Masum Olamiyon, Mirzo Sodik Jondory, and others. In the second half of the XIX century, great poets, painters Ahmad Donish, Shokhin, Savdo, Aziz Huja Aziz, Hamidbek Hamid, Somi Bustoni, and Hayrat became famous for the creativity. Their creativity still draws attention of historians and art critics, and in general, the cultural history of Uzbekistan is deeply studied and investigated.

In the second half of the XIX century Bukhara was recognized by the center of the Muslim world in the field of education and culture. Scientists, the intellectuals of Bukhara created some kind of movement for education, for cultural development, architecture, musical art. Including the poetry close and clear to the people, reflecting his hopes and dreams, in the native language began to develop. Representatives of this poetry are generally natives of Uzbek people. Especially, it should be noted creativity of the prominent scientist and philosopher, poet and artist, Ahmad Donish (1827-1894).

At that time Ahmad Donish introduced so front lines and the sharp ideas of Bukhara that they evoke our surprise. Accuracy, expressiveness, and accuracy of word are characteristic for national language. Having carried on traditions of national classical poetry, it made many positive changes to form and content of verses.

Ahmad Donish felt beauty of the nature and gave these feelings in graceful gazals who sounded as national songs. In the gazals, it sang of people of different professions - philosophers, doctors, poets, astrologers, singers in simple melodious language. The poet in the verses used apt national expressions, and in it his poetic skill is shown.

At the beginning of the XX century reached the blossoming works of the outstanding poet - the educator, the theorist, literature, the musicologist Abdurauf Fitrat (1886-1937). In 1909, he ended study in madrasa (school in Muslim countries) in Bukhara, went to Turkey and there studied and engaged in creative activity. In 1910-1914 he actively participated in work of the created association "Society of Education of Bukhara" where the talented children and young men who arrived from Bukhara and other areas of Turkistan were trained (In particular, in 1911 in Turkey, 15 messengers of Turkestan; in 1912, already 30 representatives studied). These years Fitrat wrote in the Persian-Tajik language of the books Munozara (1910), Saykh (1900), Hind sayyohi hikoyalari (1911) in which reflected a difficult life of the people and reflected on ways of reforming of society. In its program work "Rakhbari Najot" (1915) problems of reforming of society and reorganization within new historical and cultural type are comprehensively covered. This work was written in the Uzbek language, and at that time it had a great 
influence on public positions of the intellectuals. His book Uzbek Classical Music and Its History (1926) contains data on Bukhara music, valuable to us, and in particular about makom.

It is clear that from makom expert I. R. Rajabov's scientific researches in the XVIII century in Bukhara palace culture formed Shashmakom. "Bukhara had been one of the ancient culture center-capital of several dynasty and states. In music art Bukhara played the role of central city as externalized the music heritage of Central Asia nations" (Rajabov, 2006, p. 150).

\section{Conclusion}

It is possible to conclude that the musical culture and art of Bukhara created and developing since ancient times are considered traditional for the Uzbek art. With the gaining independence of one of priority tasks preservation of these invaluable traditions, finishing them as culture monuments to the younger generation and promotion in the world community. The modern youth has to make the contribution to preservation of cultural musical heritage of Bukhara.

\section{References}

Khasanov, R. (2009). Bases of fine art. Tashkent: Publishing house named after Gafur Gulom. Chekhovich, O. D., \& Andreev, M. S. (1972). Arch Bukhara (at the end of XIX-at the beginning of XX). Dushanbe: pub. Donish. Fitrat, A. (1993). Uzbek classic music and its history. Tashkent: Publishing house Fan.

Rempel, L. I. (1981). Far and near. Pages of life, life, construction business, craft and art of Old Bukhara: Bukhara records. Tashkent: Publishing house named after Gafur Gulom.

Kodirov, M. (1997). Holiday and festivals // Bukhara-East pearl. Tashkent: Sharq.

Amir Temur in world history. (2001). Added and a new second publishing. Tashkent: "Shark".

Ibragimov, O. (1994) Creation of Uzbek folk music. Tashkent: Uzbekistan Metodic Centre of Studies.

Rajabov, I. (2006). Makoms. Tashkent: Publishing house Art.

Rajabov, I. (1963). Issues of makoms. Tashkent: Publishing house Uzliterature. 